\title{
INDIVIDU, KOMUNITAS, DAN NEGARA DALAM \\ KONTEKS PEMBENTUKAN COMMUNITY CIVICS
}

\author{
Mohammad Imam Farisi dan Lukiyadi \\ FKIP Universitas Terbuka, UPBJJ-UT Surabaya \\ Email: imamfarisi@ut.ac.id
}

\begin{abstract}
Abstrak. Penelitian ini bertujuan untuk mendeskripsikan status dan peran individu, komunitas, dan negara-bangsa bagi pembentukan kewarganegaraan komunitas sebagaimana dikonstruksi di dalam buku-buku teks Ilmu Pengetahuan Sosial SD. Penelitian menggunakan teknik analisis konten kualitatif. Sumber data penelitian adalah enam buku teks elektronik IPS-SD kelas I-VI SD/MI karya Nursa'ban dan Rusmawan (2008; 2010a,b) (kelas I-III); Suranti dan Setiawan (2009a,b) (kelas IV-VI). Hasil penelitian menunjukkan bahwa secara pedagogis status dan peran individu komunitas, dan negara-bangsa bagi pembentukan kewarganegaraan komunitas dikonstruksi sejalan dengan ideologi "tertib-sosial" dan "tipe ideal" melalui penggunaan simbol, slogan, pesan, tujuan, dan gagasan, serta didukung melalui penggunaan politik kesejarahan. Persoalan-persoalan demokrasi seperti konflik sosial, isu dan masalah kontemporer dan kontroversial di wilayah tabu yang juga merupakan persoalan nyata masyarakat belum banyak diungkap karena dianggap dapat mengganggu tertib-sosial dan tipe ideal yang dicitakan.
\end{abstract}

Kata Kunci: buku teks, sekolah dasar, ilmu pengetahuan sosial, kewarganegaraan

\section{THE INDIVIDUAL, COMMUNITY, AND COUNTRY IN THE CONTEXT OF COMMUNITY CITIZENSHIP FORMATION}

\begin{abstract}
This study was aimed to describe the individual, community, and country status and roles for the formation of community citizenship as constructed in textbooks of Social Science in elementary schools. The study utilized the qualitative content analysis technique. The data sources were six electronic textbooks of Social Science for elementary school students for grades I-VI written by Nursa'ban and Rusmawan (2008; 2010a,b) (grades I-III); written by Suranti and Setiawan (2009a,b) (grades IV-VI). The findings of the study showed that the individual, community, and country status and roles for the community citizenship formation was constructed in accordance with the "social-order" and "ideal-type" ideology through the use of symbols, slogans, messages, objectives, and ideas, and supported by the use of the historical policy. Problems of democracy such as social conflicts and issues, contemporary and controversial problems in the closed areas as real community problems had not been explored because it could disrupt the social order and ideal type.
\end{abstract}

Keywords: text-book, elementary schools, social sciences, community citizenship

\section{PENDAHULUAN}

Sekalipun buku teks dikritik sebagai " $a$ frequently the product of a literary hack," namun penggunaannya dalam IPS telah dianggap sebagai "King of the King" atau "Lord of the Lord" (Saxe, 1991:98), dan hingga sekarang masih dianggap dominan, universal, dan secara empirik memiliki kedudukan dan peran sentral. Buku teks dianggap guru dan siswa sudah menjabarkan standar isi dan kurikulum (Jia, 2010). Bahkan, buku teks dipersepsi sebagai kurikulum itu sendiri (textbook-as-curriculum) (Saxe, 1991:99). Karenanya, kemudian muncul sejumlah metafora simbolik terkait dengan buku teks, seperti 'it was a textbook operation', 'it was a textbook takeoff' atau 'it was all done by the textbook.' Metafora ini secara simbolik menggambarkan betapa buku teks mampu menggambarkan beragam bentuk dan makna sosial dan perilaku secara mendalam dalam berbagai konteks (Crawford, 2003a). 
Dalam IPS, penelitian tentang buku teks atau Fuchs (2011) mengistilahkan "textbookrelated research" mulai dilakukan sejak dekade 1970an, dan dewasa ini telah berkembang menjadi subjek kajian ilmiah dan disiplin ilmiah di universitas, baik melalui perspektif "tradisi konsiliasi" yang berorientasi pada upaya menemukan pengertian bersama tentang masa lalu, dan lebih peka terhadap sejarah bangsa-bangsa lain, maupun melalui perspektif "tradisi kritis" yang lebih independen dari perspektif nasional maupun internasional (Foster, 2011).

Kajian atas buku teks IPS menarik karena dimensi jamak, pedagogis, keilmuan, ideologis, politik, sosial-budaya, politik, ekonomi, dan lainlain. Di satu sisi, buku teks IPS memang tidak selalu menjadi wahana pedagogis bagi pendidikan kewarganegaraan. Tidak sedikit konten buku teks IPS mengandung bias (sosial, etnis, agama), superfisial, dan berkualitas jelek. Bahkan, buku teks IPS-Sejarah sangat kental dengan orientasi nasionalisme-cauvinistis dengan intepretasi bias (Fuchs, 2011). Sebuah fenomena yang tidak bisa dilepaskan dari historisitasnya yang tak bias lepas dari dinamika perjuangan, kepentingan, dan tujuan-tujuan keilmuan, ideologi, politik, sosial, budaya, dan/atau ekonomi oleh rejim politik dan/ atau kelompok-kelompok kepentingan tertentu, akademisi dan/atau non-akademisi (Repoussi \& Tutiaux-Guillon, 2010).

Di sisi lain, sejalan dengan upaya akademik untuk meningkatkan kualitas pendidikan di sekolah, konten buku-buku teks IPS juga telah membuka kemungkinan baru bagi guru dan siswa untuk "the cultivation of good citizenship" dalam rangka menyiapkan mereka kemampuan untuk mengindentifikasi, mengerti, dan bekerja untuk memecahkan masalah yang dihadapi di dalam keberagaman bangsa dan di dalam dunia yang semakin penuh ketergantungan (Hammond \& Lee, 2010). Buku teks IPS juga telah mampu menyajikan konsep-konsep penting terkait berbagai aktivitas dasar manusia dalam dimensi lampau-kini secara berimbang dan akurat, serta membelajarkan siswa tentang nilai-nilai kewarganegaraan melalui sugesti dan pendekatan analisis nilai (Ersoy \& a ahin, 2012); serta memberikan peluang bagi guru untuk membantu siswa membangun pengetahuan, keterampilam, dan sikap dalam IPS (Almerico, 2013). Bahkan, hasil-hasil analisis buku teks IPS mampu memperluas wacana tentang sejumlah isu kewarganegaraan dari beragam perspektif teoretik dan empirik terkait dengan prototipe pendidikan demokrasi (Evans, 2008); tipologi kewarganegaraan; atau konsepsi multikulturalisme, yang mengedepankan makna tanggung jawab pada keharmonisan dalam agama dan ras, kohesi sosial dan meritokrasi (Ho \& Alviar-Martin, 2010).

Penelitian ini mengkaji konstruksi buku teks IPS-SD kelas I-VI tentang bagaimana status dan peran individu, komunitas dan Negara-bangsa dalam konteks pembentukan "community civics". "Community civics" dalam penelitian ini menggunakan kerangka konseptual Arthur W. Dunn (2004) yang secara akademik memberikan sebuah sociological outlook terhadap IPS. Menurutnya, community civics merupakan 'elementary sociology' yang memberikan elemen-elemen sosial atau studi sosiologis dalam IPS. Ia sekaligus juga dapat memberikan tafsir dan sudut pandang yang lebih baik tentang pemerintahan dan kewarganegaraan melalui kajian tentang karakter kehidupan komunitas kewarganegaraan nasional dan internasional dari perspektif komunitas lokal, nasional, dan global.

Melalui konsep sosiologi community civics, Dunn berharap kesenjangan antara 'teori' dan 'praktik' dalam IPS dapat dijembatani. Karena itu, Saxe (1991:22) memandang konsep community civics Dunn merupakan "the first meaningful movement from theory to practice in emerging social studies literature." Konsep community civics Dunn ni juga dipandang dapat meminimalisasi dan mengubah konsep definisional kewarganegaraan sebagai konsep politik, yang menekankan pada "formal political participation, particularly voting" menjadi konsep sosio-kultural tentang "the cultural ideal of citizenship in line with the legal status... in the public sphere" (Reuben, 1997: 406). Sementara Casper dan Krasner (2009) berpendapat bahwa konsep community civics Dunn ini merupakan "a radical departure" konsepsi pedagogis tentang pendidikan kewarganegaraan yang berkembang pada paruh pertama abad ke-20 yang sangat kental dengan dimensi politik menjadi sebuah konsep yang lebih bersifat "a-politik", dan merefleksikan pandangan bahwa "the citizen had 
to be part of a Gemeinschaft society... an organic community, in which citizenship becomes part of the identity of the individual' (h.4).

\section{METODE}

Penelitian ini menggunakan pendekatan kualitatif-interpretif dengan teknik analisis konten kualitatif yang lebih menekankan pada aktivitas "the subjective interpretation" peneliti terhadap konten/isi teks sebagai data, melalui proses kodifikasi dan indentifikasi tema-tema atau pola-pola spesifik dan menonjol (emergent), dan mengungkap "makna" (meanings) yang terdapat di dalamnya terkait dengan konstruksi kewarganegaraan dalam konteks pembentukan community civics. (Zhang, \& Wildemuth, 2009; Stemler, 2012).

Objek kajian atau interpretasi adalah "teksteks" atau "narasi tekstual" (kata, frase, kalimat, paragraf, atau dokumen tekstual secara keseluruhan) yang terdapat di dalam buku-buku teks IPS-SD kelas I-VI SD/MI. Sebuah teks di dalam tulisan adalah setiap wacana yang sudah pasti/ baku arti atau maknanya sebagaima tertulis di dalam tulisan itu sendiri. Teks bersifat otonom, yang maknanya bersifat konstitutif dari teks itu sendiri. Bahwa teks memiliki kehidupannya sendiri, ia berbeda dari intensi/maksud pengarang.

Data dikumpulkan menggunakan teknik dokumentasi, dan dianalisis secara kualitatifinterpretif menggunakan teknik "written reflective exercises", "reflective notes" atau "interpretive memos" yang memuat: (1) identitas dokumen/ sumber data; (2) pertanyaan/tema pengkategori data; (3) kutipan-kutipan kata, frase, kalimat, atau paragraf dari buku-buku teks IPS-SD yang dipandang sebagai “exemplars' yang merepresentasikan fokus penelitian; (4) dan catatan/ringkasan interpretasi-refleksi kritis peneliti atas data dan reviu teori/studi terdahulu yang relevan dengan data (Zhang \& Wildemuth, 2009).

Sumber data penelitian adalah enam buku teks elektronik (electronic textbook) IPS-SD kelas I-VI SD/MI karya Nursa'ban dan Rusmawan (2008; 2010a,b) (kelas I-III); Suranti dan Setiawan $(2009 a, b)$ (kelas IV-VI). Keenam buku teks IPS-SD tersebut dipilih karena secara substantif, muatan teks-teksnya dapat memberikan informasi atau memuat unsur-unsur yang sesuai dengan tujuan penelitian (Zhang \& Wildemuth,
2009). Buku-buku teks tersebut juga telah dinilai dan ditetapkan kelayakannya oleh Badan Standar Nasional Pendidikan (BSNP) dan Kemendikbud di dalam Peraturan Menteri Pendidikan Nasional Nomor 22 tahun 2007, Nomor 34 dan 69 tahun 2008.

\section{HASIL DAN PEMBAHASAN \\ Individu: Hidup rukun dan harmonis "di da- lam" dan "bersama" komunitas}

Konstruksi tentang individu sebagai unsur pertama komunitas-kewarganegaraan yang diharapkan dapat memberikan nilai-nilai edukatif kepada peserta didik sebagai 'clientele' tentang satus, dan makna peran serta atau partisipasinya di dalam kehidupan komunitas dan negara (Dunn, 2004).

Hasil kajian menemukan bahwa individu dikonstruksi oleh buku teks IPS-SD dalam empat status, makhluk pribadi, sosio-kultural, ekonomi, dan beragama. Individu sebagai makhluk pribadi dinyatakan 'unik, dengan kekhasan identitasidentitas primordialnya, seperti nama lengkap dan panggilan, kekerabatan, ciri-ciri fisik, umur, pengalaman, hobi, koleksi, dokumen, kesenangan, adat, atau kebiasaan (k-1)* Keunikan individupribadi ini dipandang sebagai prinsip utama untuk menumbuhkan sikap saling menghormati adanya perbedaan bagi terciptanya keteraturan, keharmonisan, dan kerukunan antar-individu di dalam komunitas.

Individu sebagai makhluk beragama adalah sosok yang mengakui bahwa segala identitas, kemampuan, aktivitas, dan/atau prestasi yang dimiliki dan diraih bukanlah karena dirinya, melainkan karena-Nya. "Bersyukur atas kemampuan rasacipta seni dan budaya yang dimiliki, prestasi yang diraih, dan lingkungan indah ciptaan-Nya" adalah karakteristik penting individu beragama (1:70-3:5-4:25-5:71). Individu sebagai makhluk ekonomi adalah makhluk produktif dan konsumtif, penghasil dan pengguna barang dan jasa atau layanan untuk memenuhi kebutuhan pribadi, komunitas dan negara. Kerja keras, disiplin, dan jujur adalah ciri-ciri semangat kerja yang tinggi yang harus dimiliki individu-ekonomi, karena pada dasarnya "semua pekerjaan itu baik" (3:43-44). Individu sebagai makhluk sosio-kultural adalah pemilik identitas kekerabatan yang mencirikan statusnya 
di dalam kehidupan komunitas keluarga-kerabat, atau komunitas pertemanan dan sekolah. Individu tak bisa hidup sendirian terpisah dari komunitasnya, melainkan harus bekerja sama dengan orang lain, dan menghargai keberbedaan sosial dan budaya individu lain. Individu adalah makhluk yang dianugerahi rasa-cipta seni dan budaya" (5:71), tetapi dalam mengekspresikan rasa-ciptanya tidak boleh menurut egonya, melainkan harus tunduk pada etika, norma aturan sosial yang diakui dan dijunjung tinggi oleh komunitas.

Dari seluruh konstruksi tentang individu tersebut, buku teks IPS-SD memandang bahwa setiap individu berhak atas tujuan masing-masing, tetapi apapun tujuannya, harus larut dan tunduk pada tujuan bersama, hidup damai, teratur, rukun dan harmonis, "rukun itu indah" (1:59). Tujuan bersama juga menetapkan peran dan tanggung jawab individu terhadap komunitas dan negara. Damai, teratur, rukun dan harmonis bukan sesuatu yang "given", melainkan berkembang secara sosio-kultural-historis melalui proses pembiasaan dan pembudayaan sejak individu hidup di dalam komunitas keluarga (k-1) dan dikukuhkan oleh ideologi negara "Bhinneka Tunggal Ika Tan Hana Dharma Mangrwa” (k-4).

Dengan demikian, seluruh konstruksi pedagogis individu yang selalu dikaitkan pada tanggung jawab sosialnya tersebut meniscayakan adanya bentuk penundukan ego-pribadi atau distorsi personalitas atas nama "tertib sosial" (Hechter \& Horne, 2003). Egoisme individu dipandang potensial merugikan diri sendiri, orang lain dan komunitasnya (1:20-21, 26-28). Pada tingkat negara-bangsa, egoisme yang berlebihan bahkan bisa melahirkan 'chauvinisme'. Sebuah sikap yang dipandang sangat membahayakan, menimbulkan persaingan, pertentangan, bahkan penjajahan, dan karenanya harus dijauhi, dihindari (4:133). Egoisme atas nama perbedaan identitas, status, dan peran individu yang berujung pada pertengkaran, konflik, atau pengingkaran atas perintah atau aturan sosial pun harus dihindari, termasuk membantah perintah ayah atau ibu (1:56).

Karenanya, perbedaan dan keberagaman individu bukan untuk dipertentangkan, atau menjadi sumber pertengkaran, melainkan wahana untuk menciptakan "hidup rukun, saling menghormati perbedaan". Individu harus saling membantu, menghargai, berbagi suka, dan patuh, saling mengasihi dalam segala perbedaan dan keberagaman suku, adat, bahasa, atau kebiasaan (1:44-61). Tanggung jawab individu adalah menjaga, mengembangkan, dan mewujudkan tujuan hidup bersama, melalui peran-peran sosialnya di dalam kehidupan komunitas. Setiap peran harus "fungsional" - sesuai fungsinya secara nyatabukan "simbolis", yang secara evolutif meluas dari komunitas terkecil (keluarga) hingga komunitas terluas (masyarakat global) (k.1-k.6).

Kalaupun relasi antar-individu sering kali 'tidak sama-sederajat', tujuan bersama komunitas harus tetap dicapai dengan membangun relasirelasi sosial dalam keserasian, keselarasan, dan keseimbangan hak dan kewajiban. Pertentangan atau konflik - apapun bentuk dan tingkatannyadistigmasi sebagai "wilayah tabu". Bagi individu yang mencoba bersikap kritis dengan melanggar tertib-sosial akan mendapat sanksi adat atau sosial, "dicemooh" (3:42), "dikucilkan dari pergaulan masyarakat" (4:95). Pengecualian dibolehkan dan ditoleransi, jika komunitas berkonsensus untuk melakukan perubahan yang diyakini "lebih baik", atau perubahan itu sebagai sebuah keniscayaan sosial yang tidak bisa dihindari (4:95-96).

Buku teks mengkonstruksi tujuh peran individu dalam kemunitas-kewarnegaraan, yaitu: warga negara, pekerja, konsumen, anggota keluarga, teman, pribadi, dan anggota kelompok sosial. Ketujuh peran sosial individu tersebut pun harus didasarkan pada 'tertib sosial' yang sudah ditetapkan dan disepakati oleh komunitas, agar tercipta keharmonisan. Setiap peran individu dikonstruksi secara 'khierarkis' (2:44), berorientasi pada 'jender', dan kodrat eksistensial individu secara sosio-biologis (2:56) yang secara kodrat ilahiah tak bisa diubah/digantikan oleh individu lain. Namun, secara sosio-ekonomis individu, komunitas, dan negara bisa bersepakat atau tidak bersepakat untuk mengubah atau menggantikannya, misalnya pertukaran peran ayah dan ibu dalam urusan ekonomi, sosial, dan lain-lain (2:44, 47-48). 


\section{Perspektif Positif dan Negatif Peran Individu Bias-Gender}

Dalam kondisi tertentu atau dalam konteks pelaksanaan "peran bersama", peran warisan individu bisa digantikan/diubah berdasarkan 'kesetaraan jender'. Konstruksi peran individu berbasis jender terutama perbedaan(bias)-jender, juga banyak diungkap oleh sejumlah peneliti dalam berbagai aspek pendidikan di sekolah (Markhamah, Suwandi \& Sudirdjo, 2006; Setyowati \& Jatiningsih, 2007). Konstruksi ini tidak hanya menjadi wacana akademik, melainkan sudah memasuki wacana epistemologis-teologis yang bersifat dekonstruktif atas status ontologis perempuan (Fadlan, 2011; Zakariya, 2011).

Dalam kaitan ini, bias-jender dalam bukubuku teks IPS-SD bisa dimaknai negatif dan/atau positif. Pemaknaan bias-jender secara negatif muncul dari pandangan dan semangat egalitarianisme individu (Setyowati \& Jatiningsih, 2007). Menurut perspektif ini, bias-gender telah mendekonstruksi perempuan secara ontologis dalam peran-peran domestik yang kemudian melahirkan ketidakadilan gender secara struktural (Fadlan, 2011). Bias-jender, apapun alasannya, dipandang tidak mendukung upaya sosialisasi jender yang egalitarian (Jatiningsih dkk., 2002:28). Dekonstruksi ini kemudian 'mendiskursif' - merelasi antara pengetahuan dan kekuasaan dalam pandangan sosio-biologis dan budaya patriarkhis masyarakat petani (Ruminiati, 2010). Bahwa memiliki anak laki-laki merupakan keharusan sebagai penerus keturunan dan kekuatan ekonomi, "banyak anak banyak rezeki” (4:203). Namun, tampaknya pada masyarakat pesisir hal ini tidak berlaku (Mulyadi, 2011).

Di sisi lain, pemaknaan bias-jender secara positif muncul dari proponen pendidikan inkuiri-reflektif yang mendukung pengembangan berpikir kritis-reflektif. Ia dapat menjadi wahana pendidikan demokrasi yang sehat, yang dicirikan oleh dialog terbuka tentang isu-isu publik, dan penguatan otonomi guru di dalam kelas. Dalam IPS, konstruksi bias-jender juga merupakan salah satu dari konten isu-isu kontroversial yang dapat menjadi bahan berpikir kritis-reflektif, yang menuntut siswa untuk memberikan pertimbangan faktual atau nilai, merumuskan asumsi-asumsi atau hipotesis-hipotesis, dan mengujinya secara terbuka (Dewey, 2010).

\section{Resiprositas Peran Sosial Individu}

Resiprositas sosial atau pertukaran peran individu dalam komunitas dikonstruksi oleh buku teks IPS-SD dalam dua tipe resiprositas sosial berdasarkan prinsip egalitarian, komunitarian, dan kepercayaan, tetapi tidak selalu menuntut kepatuhan resmi, melainkan bisa luwes, jujur, ikhlas, eksplisit untuk kemaslahatan atau keuntungan bersama kedua belah pihak.

Pertama, resiprositas peran sosial individu dilandasi oleh kepercayaan, kejujuran, kasihsayang, dan keikhlasan antar-individu baik dalam komunitas keluarga maupun komunitas sekitar. "Ibu melahirkanku, menyuapi dan menggendongku waktu kecil, menyiapkan seragamku, menyiapkan sarapanku, menemani aku makan siang sore harinya, dan menemaniku belajar", karena itu "aku sangat sayang ibu, aku sering membantu ibu, membereskan rumah, aku juga taat pada ibu" (1:39). "Sesama tetangga harus saling menolong. jika kita berbuat baik pada hari ini, suatu saat kita akan ditolong" (2:70).

Kedua, resiprositas peran sosial individu bersifat solidaritas mekanik yang diwujudkan dalam bentuk kerja sama, kerja bakti, atau gotong royong atas dasar sukarela, dan saling menguntungkan secara personal dan komunal secara timbal-balik, bukan motif-motif ekonomi, melainkan untuk mempercepat penyelesaian pekerjaan, menghemat tenaga, mempererat persaudaraan, dan terciptanya rasa aman (2:76-77).

Ada tiga pola dalam resiprositas ini. Pola pertama, 'one-to-one reciprocity', resiprositas peran antar dua individu untuk saling meringankan pekerjaan, seperti saling membantu antar-tetangga yang membutuhkan (k.2-k3). Sinoman dan Sambatan termasuk pola ini. Pola kedua, 'one-to-many reciprocity', resiprositas peran individu untuk komunitas, seperti ronda malam atau siskamling untuk keamanan lingkungan" $(2: 74 ; 3: 31)$; kerja bakti membersihkan jalan kampung (3:30). Pola ketiga, 'many-to-one reciprocity', resiprositas peran komunitas untuk individu, seperti "gotong royong membantu salah seorang warga yang terkena musibah" $(2: 73 ; 3: 29)$. 


\section{Komunitas: Tipe Ideal Kehidupan Kolektif Individu}

Buku-buku teks IPS-SD, mengkonstruksi komunitas dalam enam tipe: keluarga, pertemanan, sekolah, sekitar/tetangga, suku bangsa, dan global. Ketujuh komunitas pada prinsipnya memiliki tujuan dan peran sama, membantu individu membangun kehidupan kolektif dalam kerukunan, keharmonisan, ketenangan, dan kedamaian, dalam segala keberagaman yang dimiliki oleh individuindividu anggotanya. Keenam konstruksi tentang komunitas tersebut difokuskan pada pemberian nilai-nilai edukatif kepada peserta didik sebagai 'clientele' tentang kehidupan komunitas-lokal hingga global—sebagai "actual civic situations" (Dunn, 2004:1).

\section{Komunitas Keluarga}

Keluarga adalah komunitas pertama bagi individu, mengenal anggota keluarga inti dan kerabat dekat yang memiliki hubungan sedarahsekandung-sesaudara. Keluarga adalah tempat individu pertama kali bersosialisasi, mengenalkan dirinya; dan mengenal individu-individu lain; mendapatkan pengasihan dan pengayoman; mendapatkan kasih sayang; mempelajari kebiasaan, budaya, dan tatakrama kehidupan komunitas (kepatuhan, ketaatan, dan rasa hormat); dan mendapatkan kehidupan sosial rukun, harmonis, tenang, dan damai. "Kita harus rukun dalam keluarga walaupun setiap anggota keluarga memiliki keberbedaan hobi, agama, bahasa, dan suku karena membuat hidup kita menjadi tenang" (1:55-60).

Penyataan bahwa "rumah tempat berteduh dan berlindung dari binatang buas" (3:7) dapat dipandang sebagai metafora yang mengkiaskan peran sebuah 'mikrokosmos' komunitas-keluarga bagi siapapun individu yang mengharapkan kerukunan, keharmonisan, ketenangan, dan kedamaian. Siapapun yang akan membangun rumah harus senantiasa menjaga keseimbangan dengan 'makro-kosmos', dengan memilih lahan yang baik, hidup rukun, damai, dan harmonis dengan lingkungan dan pemandangan alam sekitar yang nyaman, segar, dan indah (3:bab-1).

\section{Komunitas Pertemanan dan Sekolah}

Pertemanan adalah komunitas temansebaya-sepermainan individu-individu untuk memenuhi kebutuhan sosialisasinya, juga untuk bertukar pengalaman, mengembangkan kesamaan kesenangan, hobi, koleksi, dokumen, dan kebiasaan. Sedangkan sekolah adalah komunitas ketiga bagi individu untuk mendapatkan pendidikan, mengembangkan kesenangan, hobi, juga bersoalisasi dengan individu-individu lain lebih luas, termasuk dengan guru dan individu-individu lainnya (3:8). Di sekolah individu juga dapat memenuhi kebutuhan ekonomi dan sekolahnya melalui kantin dan koperasi sekolah (3:52-53).

\section{Komunitas Sekitar}

Komunitas sekitar terdiri dari: (1) komunitas sekitar-pedesaan, yakni para tetangga dengan asal-usul, kebiasaan, dan pekerjaan yang relatif homogen; dan (2) komunitas sekitar-perkotaan (miskin dan kaya), yakni para tetangga dengan asal-usul, kebiasaan, dan pekerjaan yang sangat heterogen (4:33). Kedua tipe komunitas sekitar menjadi lingkungan sosial bagi individu untuk lebih mengembangkan dan memperluas kebutuhan-kebutuhan pribadi dan sosialnya, namun secara sosial, budaya, ekonomi, dan demografis keduanya berbeda. Keduanya juga memiliki hubungan fungsional terutama dalam memenuhi kebutuhan ekonomi masing-masing (4:155).

Komunitas sekitar-desa menyediakan ruang bagi individu untuk belajar dan berpartisipasi aktif di dalam berbagai aktivitas kolektif seperti kerja sama, kerja bakti, tolong-menolong, gotongroyong, dan siskamling untuk mencapai tujuan bersama komunitas. Selain itu, aktivitas-aktivitas tersebut banyak memberikan manfaat bagi individu, seperti mempercepat penyelesaian pekerjaan, menghemat tenaga, memperoleh keuntungan timbal-balik, dan saling mengenal baik identitas dan karakteristik masing-masing bagi terciptanya rasa persaudaraan yang erat, dan rasa aman bagi komunitas secara keseluruhan sebagai "ciri khas kepribadian bangsa Indonesia" (2:67-77). Makna terpenting dari aktivitas-aktivitas kolektif bagi individu adalah menundukkan ego-pribadi atau distorsi personalitas ke dalam tatanan tertib sosial (Hechter \& Horne, 2003). 
Konstruksi lingkungan alam dan buatan yang menyuguhkan "keindahan, keteduhan, dan kesegaran panorama alam" yang mengitari kehidupan komunitas sekitar-desa (3:2-7) memberikan wahana pedagogis bagi individu untuk berperan serta dalam memelihara, melestarikan, dan menjaganya dari kerusakan akibat perbuatan manusia (3:6-11). Kegiatan ekonomi komunitas sekitar yang bertumpu pada sumber daya alam dan padat karya juga menyediakan bagi individu ruang interaksi-komunikasi langsung secara lebih intensif (3: 37-46). Komunitas sekitar-desa juga dihadapkan pada berbagai peristiwa alam seperti gunung meletus, gempa bumi, banjir, angin topan, erosi, dan lahan kritis yang disebabkan oleh alam atau perbuatan manusia (6:97-116) yang menuntut tanggung jawab dan peran individu, masyarakat, dan negara untuk mengatasinya.

Komunitas sekitar digambarkan sebagai kelompok individu dengan heterogenitas asalusul dan kebiasaan (4:33) yang berurbanisasi ke kota untuk mendapatkan penghidupan yang lebih layak. Di dalam komunitas sekitar (kota-miskin) individu harus belajar dan hidup dengan berbagai persoalan, seperti perumahan kumuh dan padat, lingkungan kurang sehat, serta bagaimana mengatasinya (4:204), dan 'kehidupan keras' para pedagang kaki lima (PKL), pedagang asongan, atau warung (4:151).

Sementara komunitas sekitar (kota-kaya) hidup di rumah-rumah permanen yang dibangun dari semen atau beton dengan bentuk rumah disesuaikan dengan selera masing-masing. Di dalam komunitas sekitar (kota-kaya) individu belajar dan hidup dengan aktivitas ekonomi non-natura, seperti perdagangan, industri, jasa, perhubungan, dan bangunan yang bertumpu pada keunggulan teknologi produksi, komunikasi, dan transportasi (4:150-154). Tetapi individu kota-kaya tidak lagi bisa belajar tentang budaya silaturahmi, atau budaya saling mengunjungi, karena cara bersilaturahmi komunitasnya menggunakan berbagai perangkat komunikasi seperti surat, telegram, telepon, kartu lebaran, email, dan pesan singkat tertulis (SMS) (4:96).

Buku teks juga mengungkap permasalahan sosial komunitas kota, seperti arus urbanisasi yang tinggi, persebaran penduduk tidak merata, kualitas penduduk yang rendah yang hanya meng- hadirkan peran negara (4:199-208), sementara apa peran individu dan komunitas sama sekali tidak diungkap.

\section{Komunitas Suku-Bangsa}

Suku-bangsa adalah komunitas tempat individu bersosialisasi, mengenal dan belajar lebih jauh tentang keragaman budaya seperti senjata tradisional, pakaian adat, lagu daerah, tarian daerah, rumah adat, alat musik, seni pertunjukan, upacara adat, dan kebiasaan; serta bagaimananya menghargai dan menjaga kelestariannya.

Di dalam komunitas suku bangsa ini pula, individu belajar dan hidup dalam satuan-satuan kerukunan hidup suku bangsanya, seperti Gampong Aceh, Beo NTT, Nagari Minangkabau, Rumah Panjang Minahasa, atau Rumah Jejer BugisMakassar (4:86-97; 5:69-75) yang dilandasi oleh nilai-nilai dasar: kepercayaan, kejujuran, sukarela, keikhlasan, saling menghargai, dan kepatuhan.

\section{Komunitas Global}

Di dalam komunitas global individu belajar tentang komunitas-komunitas di seluruh negarabangsa di dunia, dan membuka diri bergaul dengan bangsa lain di dunia. Kemajuan teknologi informasi (internet), telekomunikasi, dan transportasi yang telah membentuk, mengembangkan, dan menyatukan mereka memberikan pembelajaran bagi individu tentang arti globalisasi. Di dalam komunitas global ini pula, individu belajar tentang hubungan kerja sama dan persahabatan dengan penduduk di seluruh dunia dan melakukan perdagangan bebas tanpa dibatasi oleh peran dan batasbatas antarnegara. Individu juga bisa mengenal, belajar, dan menyebarkan nilai-nilai dan budaya tertentu dari/ke seluruh dunia (6:119-127).

Keenam komunitas di atas dikonstruksi buku teks dalam dua tujuan yang bersifat komplementer. Pertama, komunitas sebagai "real community", bentuk kehidupan kolektif individu sebagai ruang sosial, budaya, ekonomi, dan politik bagi individu untuk melaksanakan peran-peran sosialnya secara nyata untuk mencapai tujuan bersama. Kedua, komunitas sebagai 'tipe ideal' bagi kehidupan kolektif individu sebagai organisasi kosmis 'masyarakat etik' yang dibangun berdasarkan norma-norma dan nilai-nilai dasar tertentu yang disepakati bersama yang dicitrakan 
bersama; atau "komunitas etik" yang menekankan kerjasama dan dan saling hormat antara warga negara dan bangsa sebagai landasan idealnya (Niiniluoto, 2011).

Untuk membangun kolektivitas dan kohesivitas individu, dan menghindarkan komunitas dari situasi "keos" yang dapat mengganggu ketertiban sosial, buku teks mengkonsepsikan bahwa setiap komunitas memiliki "tipe ideal", yaitu sebuah 'thoughtful pictures' bagi setiap tujuan, nilai, emosi, sikap dan kebiasaan individu tentang keteraturan, keharmonisan, kerukunan, dan kedamaian kehidupan komunitas yang dicitrakan. Nilai-nilai budaya komunitas yang terdapat di dalam budaya silaturahmi, adat istiadat, upacara adat, dan upacara keagamaan, sekalipun tidak tertulis, sangat penting bagi individu, bagi terciptanya kohesi komunitas yang kuat, sekaligus menjadi instumen budaya untuk membentuk dan melestarikan "kepatuhan penduduk terhadap lingkungan tempat tinggalnya"(4:95-96). "Sanksi sosial, seperti pengucilan dari pergaulan masyarakat bagi siapapun yang melanggar kebiasaan atau adat istiadat di lingkungannya" (4:95) juga merupakan peran penting tipe ideal komunitas. Hidup berdampingan tanpa permusuhan, dan saling menghargai tradisi masing-masing juga merupakan tipe ideal komunitas tentang prinsip-prinsip dasar kerukunan hidup bersama. Bhinneka Tunggal Ika Tan Hana Dharma Mangrwa, walaupun berbedabeda tetapi tetap satu juga merupakan tipe ideal komunitas lainnya yang diklaim sebagai prasasti sejarah tentang kerukunan hidup antar-komunitas suku bangsa di Indonesia.

Bagi komunitas, keberagaman sosialbudaya yang disebabkan oleh letak kultur historis wilayah, perbedaan lingkungan dan bentang alam, kepercayaan dan kebudayaan, serta keterikatan setiap komunitas pada wilayah tempat tinggalnya (k-5), bukan alasan untuk tidak menjaga persatuan dan kesatuan, melainkan khasanah dan kekuatan untuk membangun keutuhan komunitas. Keberagaman diakui mempunyai potensi terjadi perpecahan, namun kearifan setiap komunitas untuk menghindari segala hal yang dapat memicu perpecahan, konflik atau pertentangan, dengan mengedepankan sikap saling menghargai, sangat dihargai (4:75).
Melalui pedagogi tentang tipe ideal ini, buku-buku teks IPS-SD secara ideologis ingin menegaskan bahwa eksistensi individu dalam komunitas mempunyai potensi yang dapat menggangu keteraturan, kerukunan dan keharmonisan (Mulder, 2000). "Banyaknya penduduk dan suku bangsa mempunyai potensi terjadi perpecahan. Kita harus menghindari segala hal yang memicu perpecahan Negara Kesatuan Republik Indonesia (NKRI), sesuai cita-cita awal pendirian bangsa ini. Persatuan harus diutamakan meskipun kita berbeda-beda. Keanekaragaman yang dimiliki komunitas Indonesia bukan merupakan penghalang untuk mewujudkan persatuan dan kesatuan" (4:75-76). Otonomi daerah—sebagai evolusi keberagaman individu dan komunitas dalam konteks politik kenegaraan - juga harus tunduk kepada otoritas politik negara (pemerintah pusat).

\section{Negara: Melindungi Individu dan Komuni- tas}

\section{Konsep Negara: Sosial-budaya dan Politik}

Konstruksi buku teks IPS-SD tentang negara sebagai unsur ketiga komunitas-kewarganegaraan banyak difokuskan pada paradigma negara sebagai kesatuan sosial dan budaya (social and cultural entity) dan negara sebagai kesatuan politik (politicial entity) dengan peran utama yang sama, yakni melindungi kehidupan individu dan komunitas. Melalui konstruksi ini, buku teks berharap dapat memberikan nilai-nilai edukatif kepada peserta didik sebagai 'clientele' tentang satus, peran (operasi dan mekanisme kerja) negara-pemerintah di dalam melindungi tujuan dan kebaikan bersama (Dunn, 2004). Negara sebagai kesatuan sosial-budaya dimaknai oleh buku teks sebagai kesatuan sosial-budaya dari beragam komunitas kewarganegaraan dan merupakan puncak evolusi dari kehidupan berbagai komunitas kewarganegaraan.

Dengan paradigma ini, buku teks hendak menegaskan bahwa negara seperti halnya komunitas pada prinsipnya sama, memiliki tujuan dan peran sama, membantu individu dan komunitaskomunitas di dalamnya membangun kehidupan kolektif berdasarkan pada prinsip kerukunan, keharmonisan, ketenangan, dan kedamaian, dalam segala keberagaman yang dimiliki oleh anggotanya. Melalui konstruksi ini, buku teks 
IPS-SD berharap dapat memberikan nilai-nilai edukatif kepada peserta didik sebagai 'clientele' tentang satus, peran (operasi dan mekanisme kerja) negara-pemerintah di dalam melindungi tujuan dan kebaikan bersama (Dunn, 2004).

Deskripsi tentang negara sebagai kesatuan sosial dan budaya sudah diperkenalkan oleh buku teks IPS-SD sejak kelas I-VI melalui deskripsi tentang keberagaman suku, etnis, budaya, tradisi, adat-istiadat, dan semacamnya. Di kelas I SD pula, falsafah dan dasar kerukunan hidup bangsa Indonesia yang disimbolisasi melalui semboyan "Bhinneka Tunggal Ika" sudah diperkenalkan dalam realitas kehidupan individu, keluarga, dan komunitas sekitar. Pemaknaan negara secara sosial-budaya-historis ini mirip dengan pandangan Ernest Renan (1882) yang mendefinisikan negara-bangsa sebagai "a group of people who had decided to live together, a group of people which had done great things in the past and which wanted to do more in the future." Sebuah definisi yang kini masih populer digunakan dalam pandangan masyarakat Jerman terkait dengan gagasan tentang "Verfassungspatriotismus" yaitu "patriotism towards the constitution of one's country" yang merupakan pemaknaan lebih luas dari konsep multikulturalisme.

Dewasa ini, konsep negara secara sosialbudaya menjadi sangat penting terutama ketika kehidupan negara modern dihadapkan krisis yang merujuk pada adanya pemisahan antara negara (state) dan bangsa (nation). Melalui konsep ini buku teks diharapkan memberikan perspektif segar terhadap konsep negara-bangsa tentang makna "learning to live together" dalam kehidupan yang sangat jamak seperti Indonesia. Bahwa negara adalah "one where the great majority are conscious of a common identity and share the same culture" (UNESCO, 2015).

Konsep negara sebagai kesatuan politik dideskripsikan melalui kepemilikan atribut-atribut dengan kenegaraan secara otonom, seperti mata uang (kelas III); batas-batas wilayah, undangundang dasar negara, bendera nasional, lambang negara, lagu kebangsaan, bahasa nasional, kekuasaan negara, warga negara, tentara, dan segala atribut dan simbol-simbol kedaulatannya (kelas IV, V). Negara sebagai entitas masyarakat politik juga dideskripsikan di dalam buku teks sebagai serta transformasi genetik dari kerajaan-kerajaan nusantara yang sarat dengan sejarah perjuangan dan perlawanan bangsa merebut, mempertahankan kedaulatan dan mengisi kemerdekaan (kelas IV-VI).

\section{Peran Negara sebagai Kesatuan Sosial-Bu- daya}

Peran negara sebagai kesatuan sosial terkait dengan penciptaan kehidupan berbangsa yang damai, teratur, rukun dan harmonis. Rukun, damai, teratur, dan harmonis itu indah dan merupakan dasar hidup serta tujuan bersama sebagai bangsa. Buku teks IPS-SD juga mendeskripsikan bahwa damai, teratur, rukun dan harmonis bukan sesuatu yang "given", melainkan berkembang secara sosio-kultural-historis melalui proses pembiasaan dan pembudayaan sejak individu hidup di dalam komunitas keluarga. Dalam konteks kehidupan berbangsa dan bernegara, semboyan bangsa "Bhinneka Tunggal Ika Tan Hana Dharma Mangrwa" menjadi sangat penting untuk mewujudkan kerukunan, kedamaian, keteraturan, dan harmonis dalam kehidupan berbangsa. Dalam konteks ini, buku teks "hadir mewakili negara" menyampaikan pesan-pesan sosio-pedagogis kepada peserta didik dalam rangka ikut mencerdaskan kehidupan anak bangsa, dan membekali mereka untuk mencapai cita-citanya menjadi putra bangsa yang terbaik, yang bermanfaat bagi nusa, bangsa, dan negara.

Dalam kaitan ini, sejak kelas I SD peserta didik sudah diperkenalkan dengan karakteristik Indonesia sebagai bangsa yang "satu" dalam keberagamannya (etnis, tradisi, budaya, adat, kebiasaan, agama, dan semacamnya). Di lingkungan keluarga (kelas I dan II) pesan-pesan tentang kerukunan, kedamaian, keteraturan, dan harmonis dalam kehidupan berbangsa disampaikan melalui deskripsi tentang makna kasih sayang antaranggota keluarga; hidup rukun dalam keluarga; dan kedudukan dan peran anggota keluarga. Di lingkungan tetangga (kelas II dan III) disampaikan melalui deskripsi tentang makna kerjasama antartetangga. Pada bagian ini juga ditekankan bahwa saling membantu, kerjasama, gotong royong, kerja bakti, dan siskamling sebagai ciri khas bangsa merupakan instrumen sosial yang digunakan oleh buku teks untuk menumbuhkan 
kesadaran persaudaraan dan menciptakan rasa aman, rukun, damai, teratur, dan harmonis dalam kehidupan sosial.

Di lingkungan suku-suku bangsa (kelas IV dan $\mathrm{V}$ ) pesan-pesan tentang kerukunan, kedamaian, keteraturan, dan harmonis dalam kehidupan berbangsa disampaikan melalui deskripsi tentang makna keragaman sosial dan budaya masyarakat; Bhinneka Tunggal Ika; pentingnya persatuan dalam keragaman bangsa Indonesia; dan sikap menghargai keragaman suku bangsa dan budaya di masyarakat. Di lingkungan antar-bangsa atau era global (kelas VI) pesan-pesan tentang kerukunan, kedamaian, keteraturan, dan harmonis dalam kehidupan antarbangsa disampaikan melalui deskripsi tentang makna peran aktif bangsa Indonesia dalam Konferensi Asia-Afrika (KAA); ASEAN; dan pengiriman Pasukan Perdamaian Garuda dalam rangka ikut berpartisipasi aktif menciptakan dan menjaga kerukunan, kedamaian, keteraturan, dan harmonis dalam pergaulan dunia internasional.

\section{Peran Negara sebagai Kesatuan Politik}

Buku teks IPS-SD mendeskripsikan peran negara sebagai kesatuan politik melalui dua peran: simbolis-ideologis; dan programatik.

Peran simbolis-ideologis negara sebagai kesatuan politik dideskripsikan buku teks melalui pembentukan ideologi dan karakter kewarganegaraan dalam rangka membangun kohesivitas individu dan komunitas warganegara dan mencapai tujuan nasional. Untuk tujuan tersebut negara menggunakan 'politik sejarah' sebagai instrumen untuk membangun pencitraan secara simbolis dan ideologis tentang nasionalisme. Sebuah ikhtiar politik sejarah yang juga lazim digunakan di berbagai negara di dunia (Repoussi \& Tutiaux-Guillon, 2010; Khine, 2013), walaupun penyajian sejarah di dalam buku-buku teks IPS-SD sangat naratif dan bertumpu pada metode kronologis, beserta tokoh-tokoh, dan bukti-bukti historisnya.

Untuk mengkonstruksi peran simbolisideologis negara tersebut, buku-buku teks IPS-SD menyuguhkan empat bukti sejarah. Pertama, ideologi Bhinneka Tunggal Ika-Sumpah Palapa - kepahlawanan dan patriotisme bangsa sebagai khasanah dan pembuktian peran sejarah bagi pembentukan negara (kelas IV). Kedua: rembug Nasional —olahraga, jambore, aksi sosialkeagamaan, diskusi budaya - dan pembangunan nasional yang merata; dan simbol-simbol, sejarah, dan sumpah kebangsaan merupakan instrumeninstrumen pemersatu dan pengikat komunitas (4:75-76). Ketiga, monumen atau tugu bersejarah untuk membangun kesadaran historis, heroisme, atau patriotisme bangsa (2:38). Keempat, simbol-simbol pemersatu seperti: burung garuda, lambang negara Indonesia yang menyimbolkan kemerdekaan bangsa (4:74-76); dasar negara Pancasila, bendera nasional Merah Putih, lagu kebangsaan Indonesia Raya, bahasa nasional bahasa Indonesia, uraian sejarah perjuangan bangsa Indonesia dalam memperoleh kemerdekaan, Sumpah Pemuda (4:76); dan upacara bendera, membangkitkan sikap kepahlawanan dan patriotisme (4:129).

Menghadapi kehidupan komunitas global, buku teks IPS-SD mengkonstruksi peran simbolisideologis negara melalui pembangunan ideologi dan citra tentang "bangga terhadap produksi dalam negeri" dan "keunggulan kompetitif bangsa". Produk dalam negeri dikonstruksi secara simbolis sebagai hasil kerja, kreativitas, dan prestasi bangsa yang secara kualitas memiliki daya saing dengan produksi luar negeri. "Jangan khawatir untuk memakai produk dalam negeri. Banggalah memakai barang-barang produksi dalam negeri, karena selain harganya cukup murah, juga memberi kesempatan kepada generasi bangsa untuk berkarya" (5:90). Negara juga mensinergikan antara nilai-nilai global dan nilai-nilai kebangsaan secara "ko-eksistensial". Namun, jika nilai-nilai global tersebut tidak sesuai dengan nilai-nilai kebangsaan kepribadian, dasar, dan pandangan hidup bangsa Indonesia, seperti kekerasan, individualisme, materialisme, pergaulan bebas, dan minum-minuman keras, harus dibatasi, dihindari, dan ditolak (6:117-128).

Upaya buku teks IPS-SD untuk membangun citra simbolis dan ideologis negara melalui eksplorasi warisan sejarah tentang nasionalisme, persatuan dan kesatuan, dipandang sangat rentan bagi lahirnya "budaya bisu" (culture of silence). Suatu konstruksi budaya dimana manusia belum sepenuhnya mampu mengucapkan "logos" mereka sendiri, dan berbicara secara otentik sebagai 
subjek. Hal ini bisa terjadi, karena politik sejarah cenderung menempatkan masa-kini sebagai realitas yang dicengkeram oleh masa-lalu yang diidealkan sebagai "taken for granted." Selain itu, penggunaan politik sejarah-simbolis-ideologis ini juga sangat rentan bagi kemungkinan lahirnya sebuah konstruksi politik budaya negara yang anti-dialogis (Trianita, Leo, \& Sinaga, 2012), dimana negara berkeras menyembunyikan isu, masalah, konflik atau pertentangan sebagai realitas yang perlu disikapi oleh setiap individu dan masyarakat (Manggeng, 2005). Dalam budaya bisu (silent culture), sulit dihasilkan individuindividu pemikir dan peneliti sosial yang skeptis, eksploratif, dan strategis (Novenanto, 2013).

Dalam kaitan ini, bisa dipahami mengapa buku-buku teks negara 'dihadirkan dalam ketakhadiran' atau sebaliknya (presence in absence atau absence of a presence). Negara hanya dihadirkan melalui 'penanda' (signifier) atau 'jejak (trace) (Derrida, 1997) berupa simbol, pesan, ideologi, tujuan, cita-cita bersama. Bisa dipahami pula, mengapa negara kemudian dipersepsi individu atau kolektif sebagai "komunitas terbayang" (imagined community) yang baru dirasakan kehadirannya, ketika individu atau kelompok dihadapkan pada situasi krisis, anomali atau bahkan revolusi (Anderson, 2001). Dalam konteks ini pula, kehadiran buku-buku teks IPS-SD sesungguhnya hanya medium pewarisan ideologi "negara teater" dari sebuah "dunia imajiner", bukan sebagai wahana pedagogis bagi terciptanya transformasi demokratis.

\section{Peran programatik}

Peran ini dideskripsikan buku teks melalui tanggung jawab negara di dalam melindungi tujuan dan kebaikan bersama, dan peran melindungi dan menjaga terpenuhinya hak-hak individu dan komunitas, serta keutuhan keduanya sebagai unsur-unsur dalam kehidupan komunitas-kewarganegaraan. Peran dan tanggung jawab negara tersebut diwujudkan melalui penyediaan dan pengembangan berbagai fasilitas, program, badan usaha negara yang disediakan untuk memenuhi hak-hak individu dan komunitas atas elemenelemen kebutuhan hidup individu/masyarakat (kesehatan, perlindungan terhadap hidup dan hak milik, rekreasi, pendidikan, keindahan warga negara, kemakmuran, komunikasi, transportasi, migrasi, dana sosial, dan perbaikan) yang oleh Dunn (2004) dinyatakan sebagai peran dan tanggung jawab utama negara terhadap seluruh warganegara. "Orang dikatakan makmur apabila sebagian besar kebutuhannya telah terpenuhi" (5:90).

Dari semua fasilitas, program, badan usaha tersebut, peran pemerintah pusat sangat menonjol, sementara peran pemerintah daerah tak banyak diungkap. Berbagai fasilitas, program, badan usaha 'pusat' yang memperlihatkan 'kehadiran negara secara nyata-aktif' di tengah-tengah warganegaranya yang dideskripsikan di dalam buku teks mencakup 11 bidang. (1) Pendidikan: sekolah, perpustakaan, gerakan orang tua asuh, wajib belajar 9 tahun, kelompok belajar paket, BOS (Bantuan Operasional Sekolah), kartu pelajar, ijazah, rapor, kantin dan koperasi sekolah (k.1-k.4). (2) Perdagangan-industri: toko, pasar (tradisional dan moderen) (k.1, k.6), koperasi (4:165-173); Tempat Pelelangan Ikan (TPI), industri otomotif seperti PT INKA, PT PAL, PT Dirgantara Indonesia, dan PT Krakatau Steel (4:152). (3) Perbankan: uang (kartal, giral), Bank Indonesia, ATM (3:61-69); (4) transportasi: pelabuhan bongkar muat barang dan transportasi antarpulau (3:6); PT Angkasa Pura, PT Pelni, PT Jakarta Lloyd, PT Gesuri Lloyd, (4:194-195), fasilitas transportasi darat, laut, dan udara (4:153); jalan, terminal, stasiun, rel, palang pintu kereta api (4:192). (4) Perijinan: surat izin mengemudi (2:8). (5) Konservasi energi dan sumber daya alam: PLTA (4:31); program-program pelestarian sumber daya alam (4:64); pembangunan berwawasan lingkungan beserta hukum dan perundangundangannya, Badan Pengendalian Lingkungan (BPL), program perlindungan terhadap tanah dan air (reboisasi), dan udara, (6:108-111).

(6) Pertanian: pupuk (3:9), irigasi, waduk (4:31-32); program intensifikasi pertanian-bibit unggul, pengolahan tanah, pengairan, dan pasca panen (4:183). (7) Rekreasi: tempat-tempat wisata (k.1); dan fasilitas olah raga: lapangan sepak bola (k.1). (8) Informasi dan komunikasi: telepon umum (k.1), SKSD (Sistem Komunikasi Satelit Domestik) Palapa (4:188), TVRI (4:190). (9) Layanan publik: balai desa, kantor polisi (k.1). Kesehatan: puskesmas, rumah sakit (k.1-k4); 
kependudukan: sensus penduduk, Keluarga Berencana (KB), Norma Keluarga Kecil dan Bahagia Sejahtera (NKKBS), transmigrasi, pemerataan pembangunan (4:201-206), akta kelahiran, KTP, surat keluarga; dan hak milik: surat kepemilikan tanah (sertifikat) (2:2-8). (10) Konservasi budaya: museum, pemugaran atau perbaikan bangunan bersejarah (4:123). (11) Penanganan masalahmasalah sosial: kemiskinan, kejahatan, kependudukan, dan lingkungan hidup (6:47-49).

\section{SIMPULAN}

Konstruksi buku-buku teks IPS-SD tentang unsur-unsur komunitas-kewarganegaraan (individu, komunitas, dan negara), serta relasi ketiganya dalam konteks hak, kewajiban dan peran-peran masing-masing, merupakan konstruksi “tipe ideal" yang 'dipilih dan diorganisasi' secara pedagogis berdasarkan fakta, konsep, dan generalisasi dari berbagai konten ilmu-ilmu sosial. Tujuannya adalah mewariskan pengetahuan, nilai, sikap, dan kebiasaan yang secara turun temurun dari generasi ke generasi dengan kontrol ketat oleh simbol, pesan, ideologi, tujuan, cita-cita bersama yang merefleksikan peran dan tanggung jawab negara.

Dengan konstruksi seperti itu, buku-buku teks IPS-SD belum menjadi wahana sosio-pedagogis bagi pembentukan pribadi siswa sebagai warga masyarakat-negara dengan kebiasaan berpikir dan berperilaku ilmiah yang kritis, kreatif dan mandiri. Sekalipun buku-buku teks IPS-SD menghadirkan negara melalui peran-peran programatiknya, namun kesan bahwa kehadiran buku-buku teks IPS-SD 'mewakili negara' masih mengindikasikan sebagai instrumen dalam proses penciptaan "budaya bisu" dengan kontrol ketat dari negara yang masih bernuansa "otoritatif" melalui peran-peran simbolis-ideologis masih sangat menonjol.

Berdasarkan hasil penelitian ini studi-studi lanjutan yang bersifat kualitatif untuk menemukan perspektif lain dari konstruksi dimensi aktifpartisipatif kewarganegaraan komunitas penting dilakukan untuk mengungkap lebih spesifik tentang bentuk-bentuk khusus kewarganegaraan seperti kewarganegaraan digital, kewarganegaraan ekologis, dan lain-lain.

\section{DAFTAR PUSTAKA}

Almerico, Gina M. 2013. Linking Children's Literature with Social Studies in the Elementary Curriculum. Journal of Instructional Pedagogies, Vol. 11, 1-13.

Anderson, B. 2001. Imagined Community: Komunitas-komunitas Terbayang. Alih bahasa O.I Naomi. Yogyakarta: Insist Press \& Pustaka Pelajar.

Casper, G., \& Krasner, Stephen D. 2009. On Citizenship. The American Interest, Vol. IV(3), 111-116.

Crawford, K. 2003a. The Role and Purpose of Textbooks. International Journal of Historical Learning, Teaching and Research, Vol. 3(2), 5-10.

Crawford, K. 2003b. Culture Wars: Serbian History Textbooks and the Construction of National Identity. International Journal of Historical Learning, Teaching and Research, Vol. 3(2), 43-52.

Derrida, J. 1997. Of Grammatology. Diterjemahkan oleh G. Chakravorty Spivak. Baltimore \& London: Johns Hopkins University Press.

Dewey, J. 2010. How We Think. Boston-New York-Chicago: D.C.Heath \& Co., Publishers. Digitalized by Universal Digital Library. [On Line] (http://archive.org/ details/howwethink000838mbp, diakses $21 \mathrm{Mei} 2013)$.

Dunn, Arthur W. 2004. Community Civics and Rural Life (digitized version). Boston-New York-Chicago: D.C.Heath \& Co., Publishers. [On Line] (http://www.gutenberg.org/ ebooks/5088, diakses 26 Maret 2014).

Ersoy, F., \& aahin, T. 2012. Examination of Social Studies Textbooks in terms of Approaches of Values Education. Educational Sciences: Theory \& Practice, Vol. 12(2), 1547-1558. 
Evans, Ronald W. 2008. The Rugg Prototype for Democratic Education. International Journal of Social Education, Vol. 22(2), 101-135.

Fadlan, 2011. "Islâm, Feminisme, dan Konsep Kesetaraan Gender dalam Al-Qur'ân". Karsa: Jurnal Sosial dan Keislaman, 19(2), 105-119.

Foster, S. 2011. Dominant Traditions in International Textbook Research and Revision. Education Inquiry, Vol. 2(1), 1-20.

Fuchs, E. 2011. Current Trends in History and Social Studies Textbook Research. CICE Hiroshima University, Journal of International Cooperation in Education, Vol. 14(2), $17-34$.

Hammond, T. C., \& Lee, J. K. 2010. "Editorial: Digital Video and Social Studies". Contemporary Issues in Technology and Teacher Education, 10(1), 124-132.

Hechter, M.; Horne, C. Eds. 2003. Theories of Social Order. A Reader. CA: Stanford University Press.

Ho, L-C., \& Alviar-Martin, T. 2010. Between Self and State: Singapore Social Studies Teachers' Perspectives of Diversity. Journal of International Social Studies, Vol. 1 (1), 20-33.

Jatiningsih, dkk., 2002. "Pengembangan Model Pendidikan di SD: Studi untuk Meningkatkan Pemahaman Jender pada Anak dalam Rangka Penyiapan Anak Menuju Tatanan Masyarakat Egalitarian”. Laporan Penelitian tahap I. tidak dipublikasikan. Surabaya: Lembaga Penelitian UNESA.

Jia, Q. 2010. A Brief Study on the Implication of Constructivism Teaching Theory on Classroom Teaching Reform in Basic Education. International Education Studies, 3(2), 197-199.
Khine, M. S. (Ed.). 2013. Critical Analysis of Science Textbooks: Evaluating instructional effectiveness. New York-Heidelberg: Springer.

Manggeng, M. 2005. "Pendidikan yang Membebaskan Menurut Paulo Freire dan Relevansinya dalam Konteks Indonesia". INTIM - Jurnal Teologi Kontekstual, No.8 Semester Genap. 41-44.

Markhamah, Suwandi, S., \& Sudirdjo. 2006. "Persepsi Pengambil Kebijakan dan Guru Terhadap Pengembangan Model Materi Ajar dan Pembelajaran Bahasa Dan Sastra Indonesia di SLTP Berperspektif Kesetaraan Jender". Jurnal Penelitian Humaniora, 7(1), 19 - 38.

Mulyadi, A. 2011. "Perempuan Madura Pesisir Meretas Budaya Mode Produksi Patriarkat". Karsa: Jurnal Sosial dan Keislaman, 19(2), 200-213.

Niiniluoto, I. (2011). The Open Society and Its New Enemies: Critical Reflections on Democracy and Market Economy. The Tampere Club Series Volume 2: Preconditions of Democracy, 1-16.

Novenanto, A. 2013. Pertanyaan tentang Metodologi Ilmu Sosial Indonesia. Diakses di http://etnohistori.org/edisional/ tanggal 2 Mei 2013.

Nursa'ban, N., \& Rusmawan. 2008. Ilmu Pengetahuan Sosial 3 untuk Sekolah Dasar dan Madrasah Ibtidaiyah Kelas III. Jakarta: Pusat Perbukuan-Depdiknas.

Nursa'ban, N., \& Rusmawan. 2010a. Ilmu Pengetahuan Sosial 1 untuk Sekolah Dasar dan Madrasah Ibtidaiyah Kelas I. Jakarta: Pusat Perbukuan-Kemendiknas.

Nursa'ban, N., \& Rusmawan. 2010b. Ilmu Pengetahuan Sosial 2 untuk Sekolah Dasar dan Madrasah Ibtidaiyah Kelas II. Jakarta: Pusat Perbukuan-Kemendiknas. 
Repoussi, M., \& Tutiaux-Guillon, N. 2010. New Trends in History Textbook Research: Issues and Methodologies toward a School Historiography. Journal of Educational Media, Memory, and Society, 2(1), 154170.

Reuben, J.A. 1997. "Beyond Politics: Community Civics and the Redefinition of Citizenship in the Progressive Era". History of Education Quarterly, 37(4), 399-420.

Ruminiati. 2010. Implikasi Teori Sosiobiologis dan Budaya Patriarkhi dalam Pembelajaran IPS-SD Berbasis Jender. Pidato Pengukuhan Guru Besar. Malang: FIP-UM.

Saxe, D.W. 1991. Social studies in schools: A history of the early years. New York: State University of New York.

Setyowati, N., \& Jatiningsih, O. 2007. Pendidikan Jender bagi Calon Guru SD dalam Rangka Penyiapannya Menjadi Agen Sosialisasi Jender di Sekolah dalam Rangka Pendekonstruksian Nilai Jender pada Anak Menuju Tatanan Kehidupan yang Egalitarian. Jurnal Pelangi Ilmu, 1(1), 27-49.

Stemler, S. 2012. An Overview of Content Analysis. Practical Assessment, Research \& Evaluation, 7(17): 1-10.

Suranti, \& Saptriarso, E.S. 2009a. Ilmu Pengetahuan Sosial 5 untuk Sekolah Dasar dan Madrasah Ibtidaiyah Kelas V. Jakarta: Pusat Perbukuan- Depdiknas.

Suranti, \& Saptriarso, E.S. 2009b. Ilmu Pengetahuan Sosial 6 untuk Sekolah Dasar dan Madrasah Ibtidaiyah Kelas VI. Jakarta: Pusat Perbukuan- Depdiknas.
Trianita, L.N., Leo, H., Tiomahita, I., \& Sinaga, P. 2012. Strategi Kebudayaan dalam Pendidikan Karakter (Studi Pemikiran Ki Hadjar Dewantara dan Paulo Freire). Prosiding the 4th International Conference on Indonesian Studies Sanur, Bali, 9-10 Februari 2012.

UNESCO. 2015. Learning to Live Together: Nation-State. Diunduh dari http://www. unesco.org/new/en/social-and-humansciences/themes/international-migration/ glossary/nation-state/.

Zakariya, N.M. 2011. "Kegelisahan Intelektual Seorang Feminis: Telaah Pemikiran Fatima Mernissi tentang Hermeneutika Hadîts". Karsa: Jurnal Sosial dan Keislaman, 19(2), 120-135.

Zhang, Y., \& Wildemuth, B. M. 2009. Qualitative analysis of content. In B. Wildemuth (Ed.), Applications of Social Research Methods to Questions in Information and Library Science (pp.308-319). Westport, CT: Libraries Unlimited.

\section{Footnotes}

*) Semua kode huruf/angka/nomor dalam […] di dalam artikel ini menunjuk pada buku teks IPS-SD yang menjadi sumber primer penelitian. (k) adalah 'kelas'; (1,2,3-6) menunjuk pada jenjang kelas; dan (:42,59,71, dsb.) menunjuk pada nomor halaman dari teks-teks yang dirujuk atau dikutip dari buku teks IPS-SD sebagai sumber primer. 